\title{
Mathematical Modelling of Change in Composition of Mold Flux in Continuous Casting of Steels
}

\author{
Akihito KIYOSE, Ken-ichi MIYAZAWA, ${ }^{1)}$ Wataru YAMADA, ${ }^{2)}$ Kunihiko WATANABE ${ }^{3)}$ and \\ Hiromi TAKAHASHI
}

Advanced Technology Laboratories, Nippon Steel Corporation, Ida, Nakahara-ku, Kawasaki, Kanagawa-ken, 211 Japan.

1) Process Technology Research Laboratories, Nippon Steel Corporation, Shintomi, Futtsu, Chiba-ken, 293 Japan.

2) Kimitsu R \& D Laboratory, Nippon Steel Corporation, Kimitsu, Kimitsu, Chiba-ken, 299-11 Japan.

3) Kimitsu Works, Nippon Steel Corporation, Kimitsu, Kimitsu, Chiba-ken, 299-11 Japan.

(Received on May 14, 1996; accepted in final form on September 9, 1996)

\begin{abstract}
A mathematical model of the reaction between mold flux and molten steel has been newly developed to estimate the change in composition of the mold flux during the continuous casting of steels and to design an optimum flux composition. The model takes into account mass transfer in the molten steel and molten flux and equilibrium reaction at the interface. On the reaction, the activities of the practical mold flux components like $\mathrm{CaO}, \mathrm{SiO}_{2}, \mathrm{Al}_{2} \mathrm{O}_{3}, \mathrm{CaF}_{2}, \mathrm{Na}_{2} \mathrm{O}$ are estimated by a statistical thermodynamic model of slag, called cell model. Comparison of calculated composition change with data obtained in the practical casting experiment of high titanium steel showed that the mathematical model is useful for the estimation of the reaction between the mold flux and the molten steel and for the design of the mold flux composition to minimize change in composition due to that reaction.
\end{abstract}

KEY WORDS: continuous casting; mold flux; mathematical model; kinetics; high titanium steel; reaction.

\section{Introduction}

Mold flux in the continuous casting of steels plays important roles mainly for lubrication between the mold and the solidifying steel and for control of heat transfer from the molten steel to the mold. The change in composition of the mold flux due to reaction with molten steel during the casting is great in the continuous casting of steels bearing strong deoxidizing elements such as aluminum and titanium. ${ }^{1-4)}$ It is important to minimize this change to prevent crack formation of the solidifying steel. Although several studies ${ }^{1,2)}$ have so far been made on estimation of composition change of the mold flux due to absorption of alumina inclusions, theoretical prediction has not been reported on the change due to reactions between practical molten steel and flux of multi-components.

In this study, a mathematical model of the change in composition of mold flux due to the reaction with molten steel was developed to estimate this change during the continuous casting of steels and to design an optimum flux composition. The validity of the model was examined by comparing the estimated results with data in practical casting experiments of high titanium steel.

\section{Mathematical Modelling}

Change in composition of mold flux is calculated by taking account of mass transfer between the flux and molten steel and the mass balance of components in both phases.

Assumptions made in the model are as follows:

(1) Rate determining steps of reaction are the mass transfer of components both in the molten flux and steel phases.

(2) Local equilibrium is established between components of the molten flux phase and those of the molten steel phase.

(3) These two phases are homogeneous.

(4) Change in composition of the mold flux due to absorption of non-metallic inclusions in the molten steel is negligible.

Under these assumptions, mass transfer of $\mathrm{Al}, \mathrm{Si}, \mathrm{Ti}$, $\mathrm{Fe}, \mathrm{Mn}, \mathrm{P}$, and $\mathrm{O}$ due to reaction between the mold flux and molten steel are calculated.

\subsection{Mass Fluxes of Components}

Mass flux of each component is calculated by a model based on the coupled reaction model, ${ }^{5}$ which is modified for the calculation of reaction between the molten flux and steel. For the reaction at the interface between the molten flux and steel expressed by Eq. (1), mass flux of component $\mathrm{X}$ can be expressed by Eqs. (2) and (3), and that of oxygen by Eq. (4)

$$
\begin{array}{r}
\mathrm{X}+n \mathrm{O}=\mathrm{XO}_{n} \ldots \ldots \ldots \ldots \\
J_{\mathrm{X}}=\frac{\rho_{\mathrm{M}} k_{\mathrm{M}, \mathrm{X}}}{100 M_{\mathrm{X}}}\left([\% \mathrm{X}]-[\% \mathrm{X}]^{*}\right)
\end{array}
$$




$$
\begin{aligned}
= & \frac{\rho_{\mathrm{F}} k_{\mathrm{F}, \mathrm{XO}}}{100 M_{\mathrm{XO}_{n}}}\left(\left(\% \mathrm{XO}_{n}\right)^{*}-\left(\% \mathrm{XO}_{n}\right)\right) \\
J_{\mathrm{O}} & =\frac{\rho_{\mathrm{M}} k_{\mathrm{M}, \mathrm{O}}}{100 M_{\mathrm{O}}}\left([\% \mathrm{O}]-[\% \mathrm{O}]^{*}\right) \ldots \ldots
\end{aligned}
$$

Regarding mass transfer coefficient in the molten steel, the folloing equation is approximately used by assuming mean contact time between the molten flux and steel of $W / 2 v_{\mathrm{M}}$ :

$$
k_{\mathrm{M}, \mathrm{X}}=2 \sqrt{\frac{2 D \overline{v_{\mathrm{M}}}}{\pi W}}
$$

According to the assumption of local equilibrium at the reaction interface, equilibrium constant of reaction in Eq. (1) can be expressed by Eq. (6).

$$
K_{\mathrm{X}}=\frac{a_{\mathrm{XO}_{n}^{*}}}{a_{\mathrm{X}}^{*} a_{\mathrm{O}}^{* n}}=\frac{\rho_{\mathrm{F}} \gamma_{\mathrm{XO}_{n}}}{100 C M_{\mathrm{XO}_{n}} f_{\mathrm{X}} f_{\mathrm{O}}^{n}} \cdot \frac{\left(\% \mathrm{XO}_{n}\right)^{*}}{[\% \mathrm{X}]^{*}[\% \mathrm{O}]^{* n}}
$$

From mass balance of oxygen at the interface, one can obtain the following relation for the simultaneous reactions:

$$
1.5 J_{\mathrm{A} 1}+2 J_{\mathrm{Si}}+2 J_{\mathrm{Ti}}+J_{\mathrm{Fe}}+J_{\mathrm{Mn}}+2.5 J_{\mathrm{P}}-J_{\mathrm{O}}=0
$$

Using the above equations, mass flux, $J_{\mathrm{X}}$, for each component can be calculated.

\subsection{Equation of Mass Balance}

Equation of mass balance for each component in each phase can be expressed as follows:

For the molten flux phase:

$$
\begin{aligned}
& \frac{\rho_{\mathrm{F}} V_{\mathrm{F}}}{100 M_{\mathrm{XO}_{n}}} \cdot \frac{d\left(\% \mathrm{XO}_{n}\right)}{d t} \\
& =\frac{\rho_{\mathrm{F}} Q_{\mathrm{F}}}{100 M_{\mathrm{XO}_{n}}}\left(\left(\% \mathrm{XO}_{n}\right)^{\circ}-\left(\% \mathrm{XO}_{n}\right)\right)+A J_{\mathrm{X}}
\end{aligned}
$$

For the molten steel phase:

$$
\frac{\rho_{\mathrm{M}} V_{\mathrm{M}}}{100 M_{\mathrm{X}}} \cdot \frac{d[\% \mathrm{X}]}{d t}=\frac{\rho_{\mathrm{M}} Q_{\mathrm{M}}}{100 M_{\mathrm{X}}}\left([\% \mathrm{X}]^{\circ}-[\% \mathrm{X}]\right)-A J_{\mathrm{X}}
$$

Mass balance for $\mathrm{Al}, \mathrm{Si}, \mathrm{Ti}, \mathrm{Fe}, \mathrm{Mn}, \mathrm{P}$ and $\mathrm{O}$ is taken into account.

\subsection{Data Used for Calculations}

The present model was applied to estimation of the composition change of mold flux for continuous casting of high titanium steel. The problem in continuous casting of this steel is that the changes in viscosity and thermal conductivity of the mold flux due to the composition change during casting often caause a breakout or crack of the solidifying shell.

Data used for calculations are given in Table 1. Equilibrium constant of reaction $K_{\mathrm{x}}$ is estimated from

\begin{tabular}{|c|c|c|c|c|c|}
\hline \multicolumn{6}{|c|}{ Casting condition } \\
\hline \multicolumn{4}{|c|}{ Consumption of mold flux } & \multicolumn{2}{|c|}{$0.45 \mathrm{~kg} /$ ton-steel } \\
\hline \multicolumn{4}{|c|}{ Thickness of molten flux layer } & \multicolumn{2}{|c|}{$0.005 \mathrm{~m}$} \\
\hline \multicolumn{4}{|c|}{ Casting velocity } & \multicolumn{2}{|c|}{$0.7 \mathrm{~m} / \mathrm{min}$} \\
\hline \multicolumn{4}{|c|}{ Size of bloom } & \multicolumn{2}{|c|}{$0.5 \mathrm{~m} \times 0.3 \mathrm{~m}$} \\
\hline \multicolumn{4}{|c|}{ Temperature } & \multicolumn{2}{|c|}{$1550^{\circ} \mathrm{C}$} \\
\hline \multicolumn{6}{|c|}{ Composition of mold flux (mass\%) } \\
\hline & $\mathrm{CaO}$ & $\mathrm{SiO}_{2}$ & $\mathrm{Al}_{2} \mathrm{O}_{3}$ & $\mathrm{Na}_{2} \mathrm{O}$ & $\mathrm{CaF}_{2}$ \\
\hline & A 26 & 43 & 5 & 12 & 14 \\
\hline & B 19 & 51 & 4 & 13 & 13 \\
\hline \multicolumn{6}{|c|}{ Composition of molten steel (mass\%) } \\
\hline $\mathrm{C}$ & $\mathrm{Si}$ & $\mathrm{Mn}$ & $\mathrm{Al}$ & $\mathrm{Ti}$ & $\mathrm{O}$ \\
\hline 0.03 & 0.34 & 0.34 & 0.044 & 0.33 & 0.0015 \\
\hline
\end{tabular}
thermodynamic data, ${ }^{6,7)}$ activity coefficients $f_{\mathrm{X}}$ and $f_{\mathrm{O}}$ are estimated from interaction parameters, ${ }^{6)}$ and $\gamma_{\mathrm{xO}_{n}}$ is estimated using the cell model. ${ }^{8)}$ Volume of the molten flux phase is calculated from the area of cross section of mold and thickness of the molten flux layer. Volume of the molten steel phase is assumed to be the same as that
Table 1. Data used for calculations.

of the molten flux phase. In the calculation, effect of volume of the molten steel phase on changes in composition of the flux and steel is small, even if the volume of the molten steel phase is varied from $1 / 10$ to 10 times as large as that of the flux phase. Mass transfer coefficient of each component in the molten steel phase is estimated from Eq. (5) with data of diffusion coefficient in molten steel, ${ }^{\text {9) }}$ width of mold, and flow velocity of molten steel at meniscus in mold, which is assumed to be $0.2 \mathrm{~m} / \mathrm{s}$. Mass transfer coefficient of each component in the molten flux phase is estimated as $1 / 10$ of that in molten steel. ${ }^{10}$ )

\section{Experimental}

To investigate the composition change of mold flux and to validate the proposed model, practical casting experiments were conducted on high titanium steel. The experimental conditions are listed in Table 1. Two kinds of mold flux were used in the casting experiment: the ratio of $\% \mathrm{CaO}$ to $\% \mathrm{SiO}_{2}$ (hereafter, written as $\mathrm{C} / \mathrm{S}$ ) in the mold flux is $0.6(\mathrm{~A})$ and $0.38(\mathrm{~B})$.

\section{Results and Discussion}

Figure 1 shows a comparison of calculated change in composition of the mold flux with that observed for high titanium steel. The concentration of $\mathrm{TiO}_{2}$ in molten flux increases and that of $\mathrm{SiO}_{2}$ decreases, because $\mathrm{SiO}_{2}$ in the flux is reduced by $\mathrm{Ti}$ in the molten steel during the casting. In this case, there is little change in the concentration of $\mathrm{Al}_{2} \mathrm{O}_{3}$. The calculated result is in good agreement with the observed one. Change in composition of the mold flux becomes small after $20 \mathrm{~min}$ in the casting period, because the concentration of each component in molten flux changes as a result of the reaction so that it is close to a value in equilibrium with the molten steel by the reaction under a constant feeding rate of the mold flux. Calculated change in composition of molten steel and that in concentration of components except $\mathrm{SiO}_{2}, \mathrm{TiO}_{2}$ and $\mathrm{Al}_{2} \mathrm{O}_{3}$ in the flux are negligible, which is confirmed by the casting experiment. 


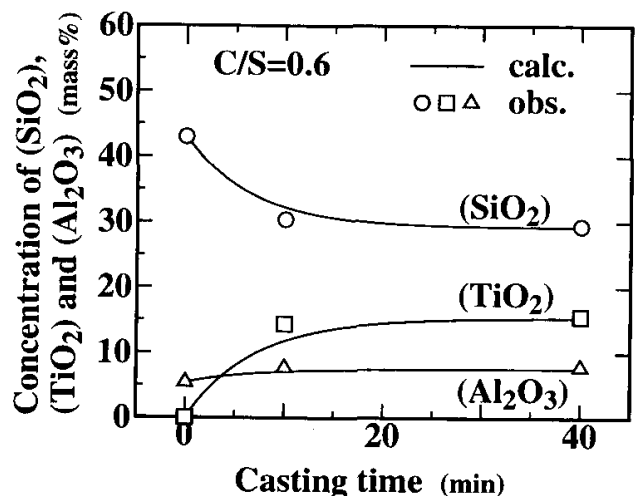

Fig. 1. Comparison of calculated composition change of mold flux during continuous casting of high titanium steel with observed one.

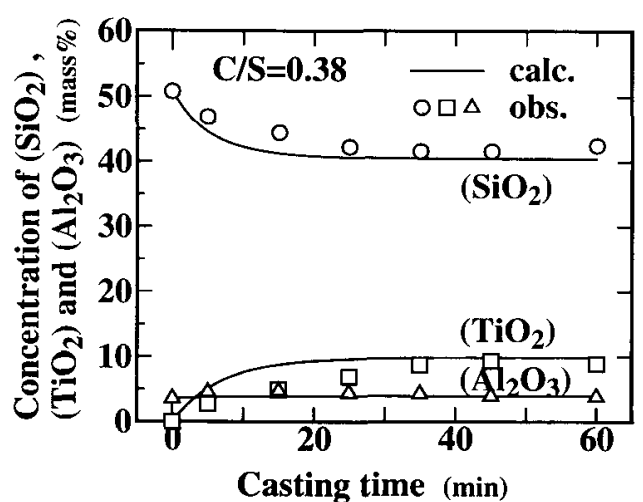

Fig. 2. Comparison between calculated composition change of mold flux and observed one for $\mathrm{C} / \mathrm{S}$ of 0.38 .

Because the calculated result of the effect of $\mathrm{C} / \mathrm{S}$ in mold flux on increase in concentration of $\mathrm{TiO}_{2}$ suggested that the composition change in the mold flux for high titanium steel could be suppressed by decreasing the value of $\mathrm{C} / \mathrm{S}$, as described below, mold flux for $\mathrm{C} / \mathrm{S}$ of 0.38 was used in a casting experiment. Observed and calculated changes in composition of the mold flux with $\mathrm{C} / \mathrm{S}$ of 0.38 for high titanium steel are shown in Fig. 2. Open marks and solid lines represent the observed and the calculated values, respectively. The change in composition of the mold flux is smaller for $\mathrm{C} / \mathrm{S}$ of 0.38 than for $\mathrm{C} / \mathrm{S}$ of 0.6 . It is seen in Fig. 2 that the calculated values are in good agreement with the observed ones.

Change in composition of mold flux should be minimized for stable casting operation. An optimum composition of mold flux for high titanium steel for reducing composition change of the mold flux is examined by the present model in the following.

Influence of $\mathrm{C} / \mathrm{S}$ on this change in composition was calculated, since $\mathrm{CaO}$ and $\mathrm{SiO}_{2}$ are main components of the mold flux. Figure 3 shows the effect of $\mathrm{C} / \mathrm{S}$ on the increase in concentration of $\mathrm{TiO}_{2}$ in the mold flux at 40 min after the start of casting; the concentration increases with the increase in $\mathrm{C} / \mathrm{S}$, agreeing with results in previous studies. ${ }^{3.4)} \mathrm{A}$ sharp increase of $\mathrm{TiO}_{2}$ in the mold flux can be seen when the value of $\mathrm{C} / \mathrm{S}$ is larger than 0.5 . This result can be examined from the thermodynamic consideration. Iso-activity lines of $\mathrm{TiO}_{2}$ of the mold flux calculated by the cell model ${ }^{8)}$ are shown on a

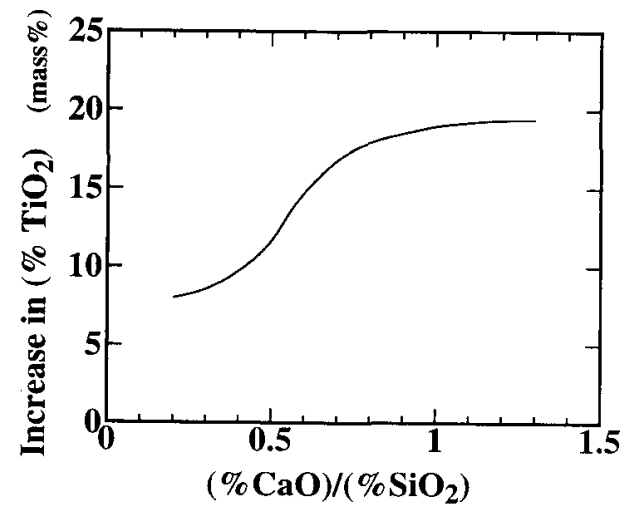

Fig. 3. Estimated effect of $(\% \mathrm{CaO}) /\left(\% \mathrm{SiO}_{2}\right)$ in the mold flux on increase in $\left(\% \mathrm{TiO}_{2}\right)$.

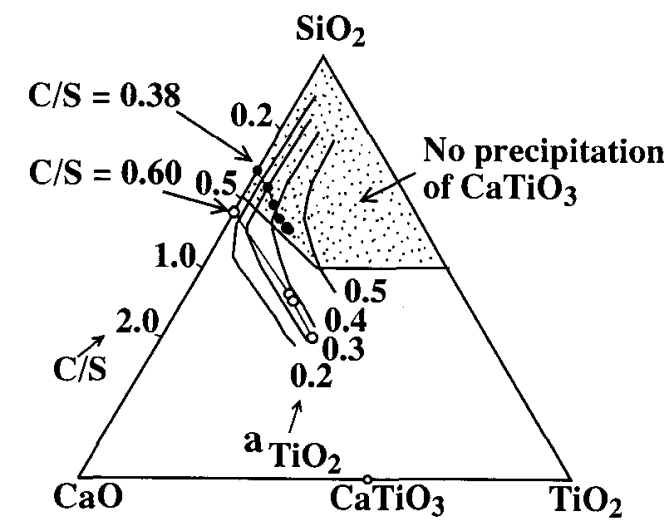

Fig. 4. Estimated iso-activity lines of $\mathrm{TiO}_{2}$ in mold flux and change in composition of mold flux for high titanium steel on $\mathrm{CaO}-\mathrm{SiO}_{2}-\mathrm{TiO}_{2}$ quasi-ternary phase diagram.

CaO- $\mathrm{SiO}_{2}-\mathrm{TiO}_{2}$ quasi-ternary phase diagram in Fig. 4. The activity of $\mathrm{TiO}_{2}$ is high when $\mathrm{C} / \mathrm{S}$ value is below 0.5 , but it becomes lower when the value is larger than 0.5 on the condition that concentration of $\mathrm{TiO}_{2}$ is constant. This is one reason why the increase in concentration of $\mathrm{TiO}_{2}$ becomes remarkable for a $\mathrm{C} / \mathrm{S}$ value larger than 0.5 . To reduce the composition change of the mold flux for high titanium steel, the value of $\mathrm{C} / \mathrm{S}$ in the mold flux to be fed should be below 0.5 .

The observed changes in composition of the mold flux for $\mathrm{C} / \mathrm{S}$ of 0.6 and 0.38 are also plotted in Fig. 4 by open and solid marks, respectively, where the change for $\mathrm{C} / \mathrm{S}$ of 0.38 is clearly smaller than that for $\mathrm{C} / \mathrm{S}$ of 0.60 . When $\mathrm{C} / \mathrm{S}$ in mold flux is 0.38 , there is no precipitation of solid $\mathrm{CaTiO}_{3}$ phase in the molten flux, which is harmful for stable casting. For optimum design of the mold flux, then, the composition change should be closed in the region without precipitation of $\mathrm{CaTiO}_{3}$ shown in Fig. 4, by lowering the value of $\mathrm{C} / \mathrm{S}$.

The present mathematical model is thus found useful not only for the estimation of the reaction between the mold flux and the molten steel, but also for the design of the mold flux composition to minimize change due to the reaction with molten steel.

\section{Conclusion}

A mathematical model of change in composition of mold flux due to reaction with molten steel during con- 
tinuous casting was developed for the theoretical prediction of the composition change and for an optimum design of mold flux. The model was applied to the continuous casting of high titanium steel.

(1) During the casting of high titanium steel, $\mathrm{TiO}_{2}$ in the mold flux increases and $\mathrm{SiO}_{2}$ decreases, because $\mathrm{SiO}_{2}$ is reduced by $\mathrm{Ti}$ in the molten steel. The composition change calculated by the present model is in good agreement with data obtained in the casting of high titanium steel.

(2) According to the model, the composition change of the mold flux for high titanium steel can be suppressed by decreasing the ratio of $(\% \mathrm{CaO})$ to $\left(\% \mathrm{SiO}_{2}\right)$ in the mold flux, which has been confirmed by the practical casting experiment. This comes from that the activity of $\mathrm{TiO}_{2}$ increases with decreasing the ratio of $(\% \mathrm{CaO})$ to $\left(\% \mathrm{SiO}_{2}\right)$ in the multi-components flux, which was estimated in this study.

(3) The present mathematical model is found useful not only for the estimation of the reaction between the mold flux and the molten steel, but also for the design of the mold flux composition to minimize change due to the reaction with molten steel.

\section{Nomenclature}

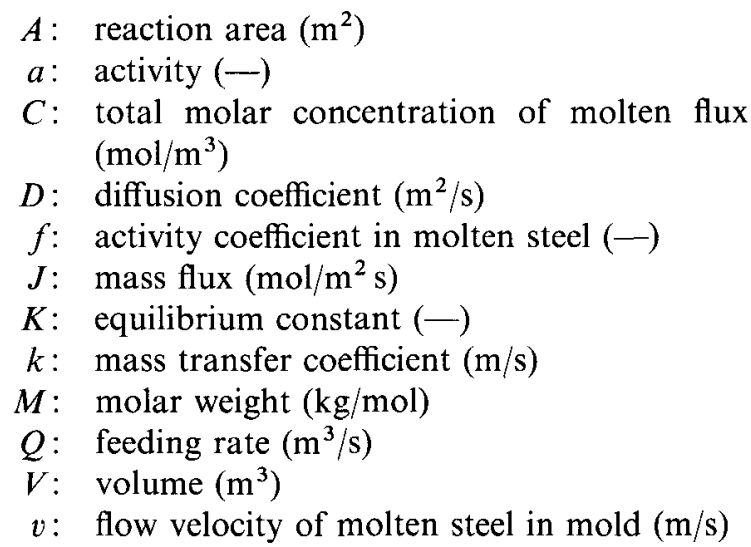

$W: \quad$ width of mold $(\mathrm{m})$

$[\% \mathrm{X}]$ : concentration of component $\mathrm{X}$ in molten steel (mass \%)

$\left(\% \mathrm{XO}_{n}\right):$ concentration of component $\mathrm{XO}_{n}$ in mold flux (mass\%)

$\gamma:$ activity coefficient in mold flux $(-)$

$\rho:$ density $\left(\mathrm{kg} / \mathrm{m}^{3}\right)$

Subscripts:
F : mold flux
$\mathrm{M}$ : molten steel
$\mathrm{O}$ : oxygen
$X$ : component $\mathrm{X}$ in molten steel phase
$\mathrm{XO}_{n}$ : component $\mathrm{XO}_{n}$ in molten flux phase superscripts
$0:$ initial
*: at reaction interface

\section{REFERENCES}

1) T. Emi, H. Nakato, K. Suzuki, Y. Iida and T. Ueda: Tetsu-to-Hagané, 60 (1974), 981.

2) T. Nakano, T. Kishi, K. Koyama, T. Komai and S. Naitoh: Trans. Iron Steel Inst. Jpn., 24 (1984), 950.

3) H. Nishikawa, I. Kimura, H. Baba, S. Moriwaki, N. Ohtani and F. Sudo: Tetsu-to-Hagané, 70 (1984), S927.

4) T. Kishi, H. Tsuboi, H. Takeuchi, T. Nakano, M. Yamamiya and S. Ando: Seitetsu Kenkyu, (1987), No. 324, 10.

5) S. Ohguchi, D. G. C. Robertson, B. Deo, P. Grieveson and J. H. E. Jeffes: Ironmaking Steelmaking, 11 (1984), 202.

6) Steelmaking Data Sourcebook, ed. by The 19th Comm. on Steelmaking, The Jpn. Soc. for the Promotion of Sci., Gordon and Breach Science Publishers, New York, NY, (1988).

7) Iron and Steel Handbook, Vol. 1, 3rd Ed., ed. by ISIJ, Maruzen, Tokyo, (1981), 15

8) J. Lehmann, H. Gaye, W. Yamada and T. Matsumiya: Proc. of 6th Int. Iron and Steel Cong., Vol. I, ISIJ, Tokyo, (1990), 256.

9) Handbook of Physico-chemical Properties at High Temperature, ed. by Y. Kawai and Y. Shiraishi, ISIJ, Tokyo, (1988), 186.

10) S. Kitamura, T. Kitamura, K. Shibata, Y. Mizukami, S. Mukawa and J. Nakagawa: ISIJ Int., 3 (1991), 1322. 